\title{
The Transcription Factor Sfp1 Regulates the Oxidative Stress Response in Candida albicans
}

\author{
Shao-Yu Lee ${ }^{1}$, Hsueh-Fen Chen ${ }^{1}$, Ying-Chieh Yeh ${ }^{1}$, Yao-Peng Xue ${ }^{1}$ and Chung-Yu Lan ${ }^{1,2, *(D)}$ \\ 1 Institute of Molecular and Cellular Biology, National Tsing Hua University, Hsinchu 30013, Taiwan; \\ s1003358@gmail.com (S.-Y.L.); g874212@gmail.com (H.-F.C.); tilamisudog@gmail.com (Y.-C.Y.); \\ t99472201@gmail.com (Y.-P.X.) \\ 2 Department of Life Science, National Tsing Hua University, Hsinchu 30013, Taiwan \\ * Correspondence: cylan@life.nthu.edu.tw; Tel.: +886-3-574-2473
}

Received: 31 March 2019; Accepted: 9 May 2019; Published: 14 May 2019

\begin{abstract}
Candida albicans is a commensal that inhabits the skin and mucous membranes of humans. Because of the increasing immunocompromised population and the limited classes of antifungal drugs available, C. albicans has emerged as an important opportunistic pathogen with high mortality rates. During infection and therapy, C. albicans frequently encounters immune cells and antifungal drugs, many of which exert their antimicrobial activity by inducing the production of reactive oxygen species (ROS). Therefore, antioxidative capacity is important for the survival and pathogenesis of C. albicans. In this study, we characterized the roles of the zinc finger transcription factor Sfp1 in the oxidative stress response against $C$. albicans. A sfp1-deleted mutant was more resistant to oxidants and macrophage killing than wild-type $C$. albicans and processed an active oxidative stress response with the phosphorylation of the mitogen-activated protein kinase (MAPK) Hog1 and high CAP1 expression. Moreover, the sfp1-deleted mutant exhibited high expression levels of antioxidant genes in response to oxidative stress, resulting in a higher total antioxidant capacity, glutathione content, and glutathione peroxidase and superoxide dismutase enzyme activity than the wild-type $C$. albicans. Finally, the sfp1-deleted mutant was resistant to macrophage killing and ROS-generating antifungal drugs. Together, our findings provide a new understanding of the complex regulatory machinery in the $C$. albicans oxidative stress response.
\end{abstract}

Keywords: Candida albicans; Sfp1; oxidative stress response

\section{Introduction}

Candida albicans (C. albicans) is a member of the human microbiota that normally inhabits the skin and mucosal surfaces of healthy individuals [1]. However, C. albicans is also an opportunistic pathogen that causes a wide range of infections including life-threatening hematogenously disseminated candidiasis, particularly in immunocompromised patients [1]. In addition to infections, C. albicans drug resistance has also emerged as a serious problem in clinical settings [2].

During the infection process and clinical therapy, the ability of $C$. albicans to adapt and respond to oxidative stress is critical for cell survival and virulence [3,4]. For example, C. albicans copes with reactive oxygen species (ROS) generation during the respiratory burst in phagocytic cells such as macrophages and neutrophils [3,5]. In addition, antifungal agents including amphotericin $B$, miconazole, and caspofungin induce ROS formation against $C$. albicans [6-8]. Previous studies showed that miconazole-mediated fungicidal activity against $C$. albicans was significantly inhibited by the addition of antioxidant [7], and superoxide dismutase inhibitors enhanced the activity of miconazole against $C$. albicans biofilm cells $[9,10]$. 
To protect cells from oxidative stress, C. albicans has evolved various signaling components, transcriptional regulatory factors, and antioxidant enzyme systems [11]. Antioxidant systems are exemplified by the superoxide dismutases (Sods), catalase, and glutathione peroxidase. Sods convert superoxide to the less toxic hydrogen peroxide, which is further detoxified to water and oxygen by catalase and the glutathione system $[12,13]$. In cell signaling, hydrogen peroxide activates the mitogen-activated protein kinase (MAPK) Hog1 by phosphorylation, and phosphorylated Hog1 promotes cell adaptation to oxidative stress [14]. However, transcription factor(s) and target genes downstream of the Hog1 pathway that respond to oxidative stress remain unknown. Moreover, independent of the Hog1-mediated pathway, the transcription factor Cap1 plays a key role in the regulation of oxidative stress response genes. Importantly, components of antioxidative systems are also associated with C. albicans pathogenesis and drug resistance. Mutant strains defective in the genes encoding Hog1, Cap1, Sods, catalase, and glutathione-related enzymes are hypersensitive to phagocyte killing and reduce C. albicans virulence in animal models of infection [15-20]. Finally, a recent study indicated that overproduction of catalase protects $C$. albicans against ROS-generating antifungals [21], indicating that the antioxidative capacity of $C$. albicans is also involved in drug resistance.

In C. albicans, Sfp1 is a transcription factor that negatively regulates the expression of adhesionand biofilm-related genes and functions downstream of the Rhb1-target of rapamycin (TOR) signaling pathway [22]. In this study, we explored other functions of Sfp1 using DNA microarray analysis and molecular genetic approaches. We found that Sfp1 is also involved in the oxidative stress response in C. albicans. The deletion of C. albicans SFP1 (sfp1 $1 / s f p 1 \Delta)$ increased the expression of antioxidant genes and antioxidant enzyme activity compared to those in wild-type strains. Moreover, the $s f p 1 \triangle / s f p 1 \triangle$ mutant promoted a higher level of $C A P 1$ gene expression and Hog1 phosphorylation. Finally, the $s f p 1 \Delta / s f p 1 \Delta$ mutant exhibited resistance to macrophage killing and antifungals with reduced ROS accumulation.

\section{Materials and Methods}

\subsection{Strains and Growth Conditions}

The C. albicans strains used in this study are listed in Table S1. Cells were routinely grown in YPD medium ( $2 \%$ glucose, $1 \%$ yeast extract, and $2 \%$ peptone) and synthetic complete (SC) medium $(0.67 \%$ yeast nitrogen base [YNB] with ammonium sulfate, $2.0 \%$ glucose, and $0.079 \%$ complete supplement mixture). Plates were prepared with $1.5 \%$ agar. For each experiment, one colony was inoculated into YPD medium and grown at $30{ }^{\circ} \mathrm{C}$ overnight. This culture was harvested by centrifugation and washed with sterile double-distilled water $\left(\mathrm{ddH}_{2} \mathrm{O}\right)$. Cells were then subcultured in $\mathrm{SC}$ medium with an initial optical density at $600 \mathrm{~nm}\left(\mathrm{OD}_{600}\right)$ of $\sim 0.5$ and further grown at $30^{\circ} \mathrm{C}$ to the exponential phase. The reagents used in this study were purchased from Sigma-Aldrich (St. Louis, MO, USA), unless indicated otherwise. For DNA microarray analysis, cells were inoculated into YPD medium at $30{ }^{\circ} \mathrm{C}$ overnight, subcultured in SC medium, and grown to the exponential phase $\left(\mathrm{OD}_{600}=1\right)$. Two independent experiments were performed for each sample.

\subsection{DNA Microarray Analysis}

DNA microarray analysis was performed as previously described [23] with some modifications. Briefly, probes for 6202 genes were designed based on the C_albicans_SC5314_version_A21-s02m09-r08_orf_coding FASTA file (Agilent Technologies, Santa Clara, CA, USA). To normalize the raw signal values, quantile normalization was used to identify differentially expressed genes. Changes in gene expression with a fold change $\geq 1.5$ and $P$-value $<0.05$ in the $s f p 1 \Delta / s f p 1 \Delta$ mutant compared to the wild type strain were considered significantly different. Microarray data were deposited in the Gene Expression Omnibus (http://www.ncbi.nlm.nih.gov/geo) under accession number GSE127184. 


\subsection{Reverse Transcription (RT) Real-Time Quantitative PCR ( $q P C R$ )}

Total RNA extraction, cDNA synthesis by reverse transcription and real-time qPCR were performed as previously described [23]. The primers used in this study are listed in Table S2. The PMA1 transcript was used as an internal control for the RNA input [24]. The relative fold change in the expression of each gene was calculated using the $2^{-\Delta \Delta C T}$ method [25].

\subsection{Extraction and Quantification of Total Protein}

Cells were grown in SC medium with or without hydrogen peroxide $\left(\mathrm{H}_{2} \mathrm{O}_{2}\right)$ or menadione for $2 \mathrm{~h}$, washed with phosphate buffered saline (PBS), and mixed with ice-cold protein extraction buffer as indicated for each assay described below. The cell suspensions were further mixed with $0.3 \mathrm{~g}$ acid-washed glass beads, disrupted by vortexing for $30 \mathrm{~s}$, and immediately placed on ice for $30 \mathrm{~s}$. This process was repeated eight times. Soluble proteins were collected by centrifugation $(13,000 \times g)$ at $4{ }^{\circ} \mathrm{C}$ and quantified using a Bio-Rad protein assay (Bio-Rad, Hercules, CA, USA) based on the Bradford method.

\subsection{Determination of Total Antioxidant Capacity}

Total antioxidant capacity was measured using the Antioxidant Assay Kit (Cayman Chemical, Ann Arbor, MI, USA) according to the manufacturer's instructions. This assay relies on the ability of cellular antioxidants to inhibit the oxidation of ABTS (2,2'-azino-di-[3-ethylbenzthiazoline sulfonate]). Protein extraction was performed as described above using an extraction buffer containing $5 \mathrm{mM}$ potassium phosphate ( $\mathrm{pH} 7.4), 0.9 \%$ sodium chloride, and $0.1 \%$ glucose. Briefly, $10 \mu \mathrm{L}$ of proteins was mixed with $150 \mu \mathrm{L}$ ABTS, followed by the addition of $40 \mu \mathrm{L} \mathrm{H}_{2} \mathrm{O}_{2}$ and $10 \mu \mathrm{L}$ metmyoglobin to initiate the reaction. After incubation at room temperature for $5 \mathrm{~min}$, the absorbance at $750 \mathrm{~nm}$ was measured spectrophotometrically. The total antioxidant capacity to prevent ABTS oxidation was compared with that of Trolox, a water-soluble tocopherol analogue. The total antioxidant capacity was expressed as molar Trolox equivalents.

\subsection{Cell Susceptibility to Oxidants and Measurement of Intracellular ROS}

Cell susceptibility to oxidants was examined by spot assay and propidium iodide (PI) staining as previously described [26]. In the spot assay, one colony was inoculated into YPD medium and grown at $30^{\circ} \mathrm{C}$ overnight. Cells were collected by centrifugation, washed, and resuspended in sterile $\mathrm{ddH}_{2} \mathrm{O}$. Cells were 10 -fold serially diluted $\left(3 \times 10^{7}\right.$ to $3 \times 10^{3}$ cells $\left./ \mathrm{mL}\right)$ and $5 \mu \mathrm{L}$ of each sample was spotted onto SC or YPD agar plates containing $\mathrm{H}_{2} \mathrm{O}_{2}$ or menadione. The plates were incubated at $30{ }^{\circ} \mathrm{C}$ for $4-5$ days and photographed every day. For PI staining, cells were treated with $\mathrm{H}_{2} \mathrm{O}_{2}$ or menadione for $2 \mathrm{~h}$, harvested by centrifugation, washed with PBS, and resuspended in a PI staining solution (4 $\mu \mathrm{g} / \mathrm{mL}$ PI in PBS). PI-positive cells were measured using an Accuri C6 flow cytometer (BD Biosciences, San Jose, CA, USA).

Intracellular ROS were detected using cell permeable $2^{\prime}, 7^{\prime}$-dichlorodihydrofluorescein diacetate $\left(\mathrm{H}_{2}\right.$ DCFDA) as previously described [27]. Briefly, cells were treated with or without $\mathrm{H}_{2} \mathrm{O}_{2}$ and menadione for $2 \mathrm{~h}$. The cells were subsequently harvested, washed with PBS, resuspended in PBS containing $20 \mu \mathrm{g} / \mathrm{mL} \mathrm{H}_{2}$ DCFDA, and incubated at $30{ }^{\circ} \mathrm{C}$ for $30 \mathrm{~min}$. The fluorescence intensity was measured using an Accuri C6 flow cytometer (BD Biosciences).

\subsection{Examination of Cell Morphology by Scanning Electron Microscopy (SEM)}

To examine cell morphology, $6 \times 10^{7}$ cells were grown on polystyrene coverslips (Thermanox plastic coverslip 174950, Thermo Scientific) that were placed in each well of a 24-well microplate containing $1 \mathrm{~mL} \mathrm{SC}$ medium with or without $30 \mathrm{mM} \mathrm{H}_{2} \mathrm{O}_{2}$. After incubation at $30{ }^{\circ} \mathrm{C}$ for $2 \mathrm{~h}$, the coverslip was washed with PBS and fixed with $3.7 \%$ formaldehyde for $40 \mathrm{~min}$. The coverslip was subsequently washed with PBS and treated with $1 \%$ osmium tetroxide for $15 \mathrm{~min}$. After fixation, 
the samples were dehydrated using serial ethanol solutions as previously described [22] and dried overnight in a $60^{\circ} \mathrm{C}$ oven. Finally, the samples were examined and micrographs were collected using SEM S-4700, Type II (Hitachi, Minato-ku, Japan).

\subsection{Measurement of Sod and Catalase Enzyme Activity}

The Sod activity was measured using a Superoxide Dismutase (SOD) Activity Colorimetric Assay Kit (BioVision, Milpitas, CA) according to the manufacturer's instructions. Protein extraction was performed as described above in an extraction buffer containing $0.1 \mathrm{M}$ Tris/ $\mathrm{HCl}(\mathrm{pH} 7.4), 0.5 \%$ Triton $\mathrm{X}-100,5 \mathrm{mM} \beta$-mercaptoethanol, and $0.1 \mathrm{mg} / \mathrm{mL}$ phenylmethylsulfonyl fluoride. Proteins $(2 \mu \mathrm{g}$ in $250 \mu \mathrm{L}$ solution) were mixed with $200 \mu \mathrm{L}$ WST Solution and $20 \mu \mathrm{L}$ SOD Enzyme Solution (BioVision) and incubated at $37^{\circ} \mathrm{C}$ for $20 \mathrm{~min}$. The absorbance at $450 \mathrm{~nm}$ was measured spectrophotometrically. The relative enzyme activity of Sod was calculated by the activity in the $s f p 1 \Delta / s f p 1 \Delta$ mutant divided by that in the wild-type strain.

Catalase enzyme activity was determined using a spectrophotometric method as previously described [28]. Briefly, $10 \mu \mathrm{g}$ of protein was mixed with potassium phosphate buffer ( $75 \mathrm{mM}, \mathrm{pH} 7.0)$ and $10 \mathrm{mM} \mathrm{H}_{2} \mathrm{O}_{2}$ to a volume of $1 \mathrm{~mL}$. The rate of $\mathrm{H}_{2} \mathrm{O}_{2}$ disappearance was detected by measuring the absorbance at $240 \mathrm{~nm}$ every $30 \mathrm{sec}$ for a total of $2 \mathrm{~min}$. One unit of catalase activity was defined as the amount of catalase required to degrade $1 \mu$ mole $\mathrm{H}_{2} \mathrm{O}_{2}$ per min.

\subsection{Measurement of Total Glutathione, Oxidized-Glutathione (GSSG), and Reduced-Glutathione (GSH) Content}

Total glutathione and GSH content was quantified using the 5,5'-dithiobis-2- nitrobenzoic acid (DTNB)-based enzymatic recycling method [29]. To measure the total glutathione content, a protein extraction buffer (0.1 M potassium phosphate [pH 7.5], $5 \mathrm{mM}$ ethylenediaminetetraacetic acid [EDTA], $0.5 \%$ metaphosphoric acid, $0.6 \%$ sulfosalicylic acid, and $0.1 \%$ Triton-X 100) was used. Twenty micrograms of protein was incubated with $60 \mu \mathrm{L}$ DTNB, $60 \mu \mathrm{L}$ glutathione reductase and $60 \mu \mathrm{L}$ NADPH for $2 \mathrm{~min}$, and the absorbance at $412 \mathrm{~nm}$ was measured.

To measure the GSSG content, cells (in $100 \mu \mathrm{L}$ protein extraction buffer) were mixed with $2 \mu \mathrm{L}$ 2-vinylpyridine (2-VP). After the cells were disrupted, their supernatants were collected by centrifugation and incubated at room temperature for $1 \mathrm{~h}$, allowing 2-VP to conjugate with GSH. Then, $6 \mu \mathrm{L}$ triethanolamine was added to neutralize 2-VP, and the mixture was adjusted to $\mathrm{pH} 6 \sim 7$. Finally, $20 \mu \mathrm{g}$ of 2-VP treated proteins were incubated with $60 \mu \mathrm{L}$ DTNB, $60 \mu \mathrm{L}$ glutathione reductase, and $60 \mu \mathrm{L}$ NADPH for $2 \mathrm{~min}$, and the absorbance at $412 \mathrm{~nm}$ was measured. The GSH content was determined using the following formula: $[\mathrm{GSH}]=[$ total glutathione $]-2 \times[\mathrm{GSSG}]$

\subsection{Measurement of Glutathione Peroxidase Enzyme Activity}

The glutathione peroxidase activity was determined using the glutathione reductase enzyme-coupling method as previously described [30] with some modifications. Proteins were extracted in an extraction buffer containing $50 \mathrm{mM}$ potassium phosphate buffer ( $\mathrm{pH} 7.2$ ) with $5 \mathrm{mM}$ EDTA. Briefly, $50 \mu \mathrm{L}$ of protein was mixed with $10 \mu \mathrm{L}$ NADPH $(40 \mathrm{mM}), 10 \mu \mathrm{L}$ glutathione reductase $(10 \mathrm{U} / \mathrm{mL})$, and $10 \mu \mathrm{L}$ glutathione $(5 \mathrm{mM})$. Then, the mixture was added to $20 \mu \mathrm{L}$ cumene hydroperoxide $(0.25 \mathrm{mM})$ to initiate the reaction. The rate of NADPH oxidation was monitored by measuring the absorbance at $340 \mathrm{~nm}$ at a 1-min interval for $5 \mathrm{~min}$. One unit of glutathione peroxidase activity was defined as the amount of enzyme that produced $1 \mu \mathrm{mol}$ of GSSG/min.

\subsection{Western Blotting}

Western blotting was conducted as previously described [31]. The anti-phospho-p38 (Thr180/Tyr182) monoclonal antibody \#9211 (Cell Signaling Technology, Danvers, MA, USA) and the rabbit polyclonal anti- $\beta$-actin antibody (GeneTex, Irvine, CA, USA) were used to detect Hog1 phosphorylation and Act1, respectively. The horseradish peroxidase (HRP)-conjugated goat anti-rabbit IgG (GeneTex) was used 
as the secondary antibody. The blots were visualized using a Western Lightning Plus-ECL Enhanced Chemiluminescence Substrate kit (PerkinElmer) and an ImageQuant LAS 4000 Biomolecular Imager (GE Healthcare Life Science, Marlborough, PA, USA).

\subsection{Macrophage Killing and Phagocytosis Assay}

The RAW264.7 mouse macrophage cell line was incubated with Dulbecco's modified Eagle medium (DMEM) plus $10 \%$ fetal bovine serum (FBS) at $37{ }^{\circ} \mathrm{C}$ with $5 \% \mathrm{CO}_{2}$. In the macrophage killing assay, C. albicans cells were cocultured with $10^{6}$ RAW264.7 cells for $16 \mathrm{~h}$ at a multiplicity of infection (MOI) of 1:10. One milliliter of sterile $\mathrm{ddH}_{2} \mathrm{O}$ was added to promote macrophage lysis, C. albicans cells were collected by scraping from the bottom of each well and then spotted onto YPD agar plates, and colony-forming units (CFUs) were counted after incubation at $30{ }^{\circ} \mathrm{C}$ for $24 \mathrm{~h}$.

In the phagocytosis assay, C. albicans cells were stained with $0.68 \mathrm{mg} / \mathrm{mL}$ fluorescein isothiocyanate (FITC) for $40 \mathrm{~min}$ and then cocultured with $2 \times 10^{6}$ cells of macrophages for $20 \mathrm{~min}$ at an MOI of 1 . Then, $5 \mu \mathrm{g} / \mathrm{mL}$ calcofluor white was added to stain the nonphagocytosed $C$. albicans cells. The rate of phagocytosis was assessed using a fluorescence microscope (AIX0, Zeiss). Data were obtained from three independent experiments by analyzing at least 300 macrophages per well.

\subsection{Statistical Analysis}

Student's $t$-test was used to assess the statistical significance of differences in the wild-type strain versus the $s f p 1 \Delta / s f p 1 \Delta$ mutant. Statistical significance was indicated with a $P$-value $<0.05$.

\section{Results}

\subsection{Sfp1 is Involved in the C. albicans Response to Oxidative Stress}

In our previous study, C. albicans Sfp1 was involved in cell adhesion and biofilm formation [22]. To reveal other functions of Sfp1, we used whole-genome DNA microarray to compare gene expression patterns between the $s f p 1$-deleted $(s f p 1 \Delta / s f p 1 \Delta)$ and wild-type strains. Among the 6,202 C. albicans genes that were evaluated, 2,365 genes exhibited a significant change in expression $(P<0.05)$ that was $\geq 1$.5-fold. Based on C. albicans genome annotation (http://www.candidagenome.org), these genes are involved in a wide variety of biological processes (Figure S1). Interestingly, a subset of genes involved in the oxidative stress response was upregulated in the $s f p 1 \Delta / s f p 1 \Delta$ mutant compared to their expression in the wild-type strain (Table 1), including GCS1 and GPX2, which encode gamma-glutamylcysteine synthetase and glutathione peroxidase, respectively. Moreover, the $s f p 1 \Delta / s f p 1 \Delta$ mutant also showed higher expression levels of genes encoding the components of oxidative stress signaling and regulation, including SSK1 and CAP1. Ssk1 is a response regulator of two-component system and functions upstream of the Hog1 mitogen-activated protein kinase (MAPK) to adapt cells to oxidative stress [32]. Cap1 is a transcription regulator that controls antioxidant gene expression [33,34].

Table 1. Relative expression of oxidative stress response genes in the sfp1-deleted vs wild-type strains. $(P<0.05)$.

\begin{tabular}{|c|c|c|c|}
\hline ORF & Gene & Function & $\begin{array}{l}\text { Relative fold change } \\
\quad(s f p 1 \Delta / \Delta: \mathrm{WT})\end{array}$ \\
\hline \multicolumn{4}{|c|}{ Transcription factor } \\
\hline orf19.1623 & CAP1 & bZIP transcription factor, responding to oxidative stress & 1.58 \\
\hline \multicolumn{4}{|c|}{ Hog MAPK pathway } \\
\hline orf19.5031 & SSK1 & Response regulator & 2.01 \\
\hline \multicolumn{4}{|c|}{ Glutathione system } \\
\hline orf19.5059 & GCS1 & Gamma-glutamylcysteine synthetase & 2.32 \\
\hline orf19.85 & GPX2 & Glutathione peroxidase & 2.27 \\
\hline orf19.6947 & GTT11 & Glutathione S-transferase & 1.65 \\
\hline
\end{tabular}


Table 1. Cont.

\begin{tabular}{|c|c|c|c|}
\hline ORF & Gene & Function & $\begin{array}{l}\text { Relative fold change } \\
\quad(\operatorname{sfp} 1 \Delta / \Delta: \mathrm{WT})\end{array}$ \\
\hline \multicolumn{4}{|c|}{ Glutathione system } \\
\hline orf19.359 & GTT12 & Glutathione S-transferase & 1.70 \\
\hline orf19.356 & GTT13 & Glutathione S-transferase & 1.71 \\
\hline orf19.6478 & YCF1 & Glutathione S-conjugate transporter & 1.79 \\
\hline orf19.5673 & OPT7 & Glutathione transmembrane transporter & 4.04 \\
\hline orf19.6402 & CYS3 & Cystathionine gamma-lyase & 2.18 \\
\hline orf19.5811 & MET1 & Uroporphyrin-3 C-methyltransferase & 3.59 \\
\hline \multicolumn{4}{|c|}{ Thioredoxin system } \\
\hline orf19.5180 & PRX1 & Thioredoxin peroxidase & 3.43 \\
\hline \multicolumn{4}{|c|}{ Oxidoreductase } \\
\hline orf19.113 & CIP1 & Oxidoreductase, induced by oxidative stress & 2.11 \\
\hline orf19.125 & EBP1 & NADPH oxidoreductase & 2.26 \\
\hline orf19.3131 & OYE32 & NAD(P)H oxidoreductase & 1.88 \\
\hline orf19.1048 & IFD6 & Aldo-keto reductase & 2.04 \\
\hline \multicolumn{4}{|l|}{ Others } \\
\hline orf19.5843 & SRR1 & $\begin{array}{l}\text { Two-component system response regulator involving in } \\
\text { multiple stress responses }\end{array}$ & 3.84 \\
\hline orf19.7293 & MPS1 & Monopolar spindle protein & 2.13 \\
\hline orf19.4772 & SHO1 & Adaptor protein & 1.87 \\
\hline orf19.2028 & MXR1 & Methionine sulfoxide reductase & 1.83 \\
\hline
\end{tabular}

To further investigate the functions of Sfp1 in the oxidative stress response, we determined the total antioxidative capacity of C. albicans. In Figure 1, the $s f p 1 \Delta / s f p 1 \Delta$ mutant showed an increase in antioxidative capacity compared to that in the wild-type and SFP1-reintegrated strains. Moreover, the total antioxidative capacity was largely enhanced in the $s f p 1 \Delta / s f p 1 \Delta$ mutant with hydrogen peroxide $\left(\mathrm{H}_{2} \mathrm{O}_{2}\right)$-induced oxidative stress. Therefore, the combined results of the DNA microarray and total antioxidant capacity assay suggested that $C$. albicans Sfp1 negatively regulates the oxidative stress response.

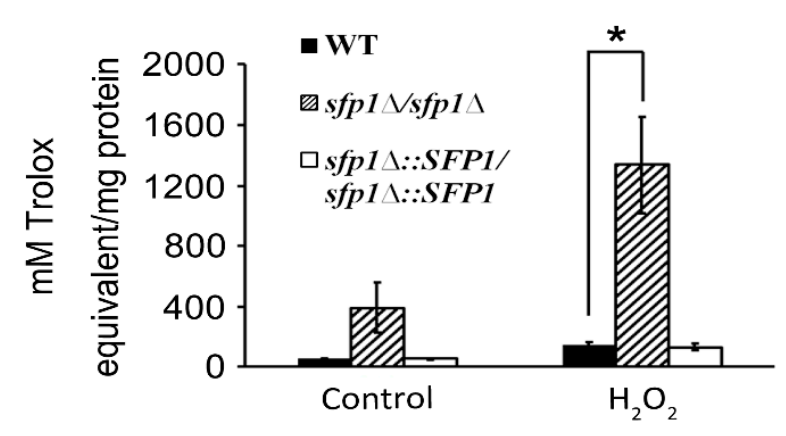

Figure 1. Total antioxidant capacity of $C$. albicans. The cells were treated with or without $1 \mathrm{mM}$ hydrogen peroxide for $2 \mathrm{~h}$. Total antioxidant capacity was measured and expressed as molar Trolox equivalents. WT: wild-type strain; $s f p 1 \Delta / s f p 1 \Delta$ : sfp1-deleted mutant; sfp1 $1:$ SFP1/sfp1 $:: S F P 1$ : SFP1-reintegrated strain. The results are presented as the mean \pm standard deviation (SD) of three independent experiments. * $P<0.05$.

\subsection{Sfp1 is Related to Cellular Susceptibility to Menadione/Superoxide}

Superoxide is a primary ROS generated by phagocytes and several antifungals. To further understand the functions of Sfp1 in the oxidative stress response, we also determined the cellular response to the superoxide generator menadione. In a cell susceptibility assay, the $s f p 1 \Delta / s f p 1 \Delta$ mutant was more resistant to menadione than the wild-type and SFP1-reintegrated strains (Figure 2A). 
Moreover, cell viability upon menadione treatment was also assessed through PI staining using flow cytometry. As shown in Figure 2B, the number of PI-positive cells was much lower in the $s f p 1 \Delta / s f p 1 \Delta$ mutant than in the wild-type and SFP1-reintegrated strains.

To further understand the correlation between Sfp1 and the cellular response to menadione-induced oxidative stress, intracellular ROS accumulation was detected. The cells were treated with sublethal doses of menadione and stained with the ROS indicator $\mathrm{H}_{2}$ DCFDA. Intracellular ROS accumulation was then measured using flow cytometry. As shown in Figure $2 \mathrm{C}$, the mean fluorescence intensity of the sfp $1 \Delta / s f p 1 \Delta$ mutant was approximately 30 -fold lower than those of the wild-type and SFP1-reintegrated cells. Together, these results indicate that the $s f p 1 \Delta / s f p 1 \Delta$ mutant is more resistant to menadione-induced oxidative stress and possesses a significantly lower intracellular ROS content upon the induction of superoxide than the other two tested strains.
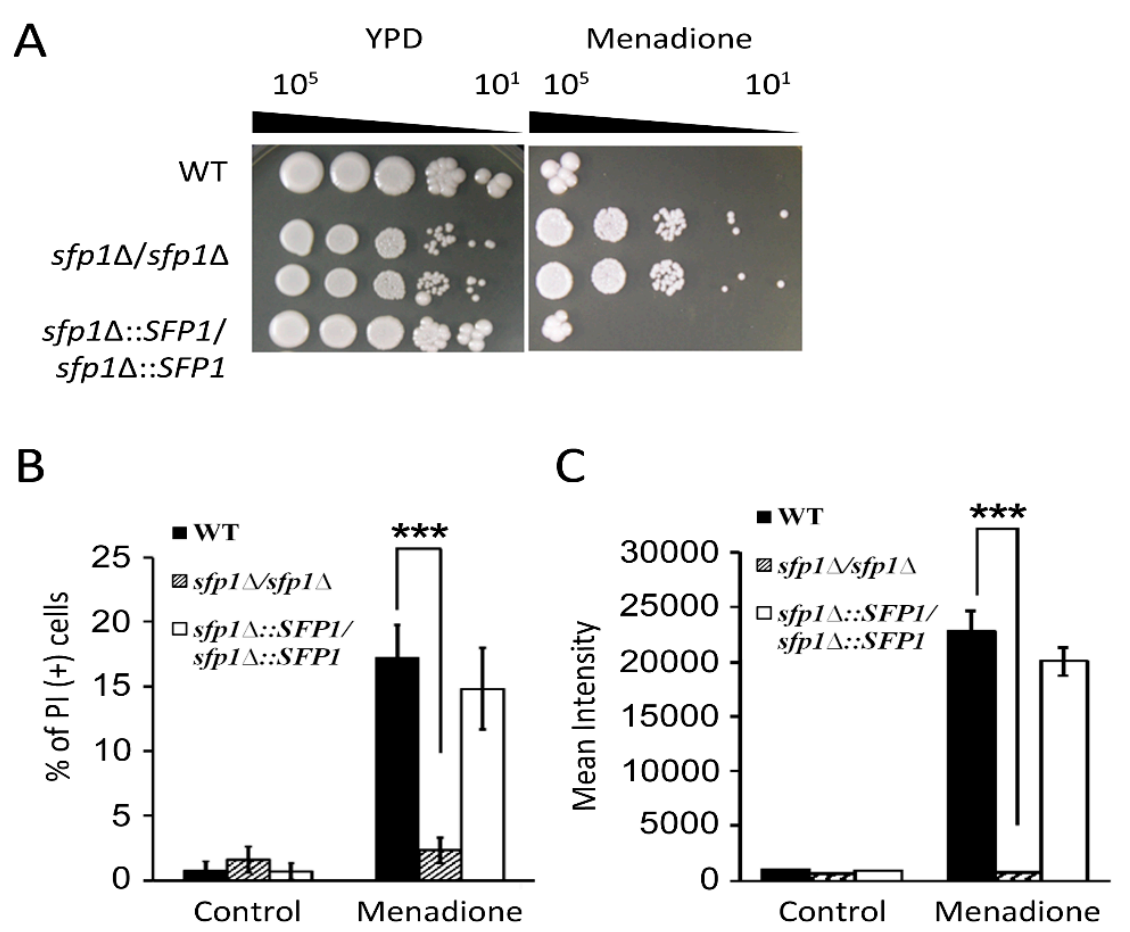

Figure 2. Susceptibility of C. albicans to menadione and menadione-induced intracellular ROS generation. (A) The cells were ten-fold serially diluted and spotted onto YPD agar plates with or without $290 \mu \mathrm{M}$ menadione. The agar plates were incubated at $30{ }^{\circ} \mathrm{C}$ for $3-4$ days. Representative images of three independent experiments with identical results are shown. (B) Cells were treated with $870 \mu \mathrm{M}$ menadione for $2 \mathrm{~h}$, stained with $4 \mu \mathrm{g} / \mathrm{mL}$ of PI, and analyzed using a flow cytometer. The dead cells are expressed as PI-positive cells. (C) Cells were treated with $290 \mu \mathrm{M}$ menadione for $2 \mathrm{~h}$ and stained with $20 \mu \mathrm{g} / \mathrm{mL} \mathrm{H}_{2}$ DCFDA. The mean fluorescence intensity of 10,000 cells was determined by flow cytometry. The results are presented as the mean \pm standard deviation (SD) of three independent experiments. ${ }^{* * *} P<0.001$.

\subsection{Sfp1 Affects SOD Gene Expression and Enzyme Activity}

In C. albicans, superoxide is mainly detoxified by superoxide dismutases (Sods) that convert superoxide into the less toxic hydrogen peroxide [4,35]. Moreover, previous studies showed that Sods are involved in the $C$. albicans response to menadione, an ROS-generating antifungal, and macrophage killing $[7,18,19]$. Because the $s f p 1 \Delta / s f p 1 \Delta$ mutant is resistant to menadione-induced oxidative stress (Figure 2A-C), we hypothesized that Sfp1 may regulate SOD expression. To test this hypothesis, SOD gene expression levels and enzyme activity were compared among different $C$. albicans strains. Based on the results of real-time qPCR analysis, the expression of the SOD1, SOD4, and SOD5 genes, but not $S O D 2$ and $S O D 3$, was significantly upregulated in the $s f p 1 \triangle / s f p 1 \Delta$ mutant with menadione treatment 
compared to that in the other two strains (Figure 3A and Figure S2). Finally, Sod enzyme activity was also measured. As shown in Figure 3B, the $s f p 1 \Delta / s f p 1 \Delta$ mutant exhibited $40 \%$ higher Sod enzyme activity than the wild-type and SFP1-reintegrated strains. These results further indicated that Sfp1 negatively regulates the cellular response to menadione/superoxide, possibly through its control of SOD gene expression and enzyme activity.

A

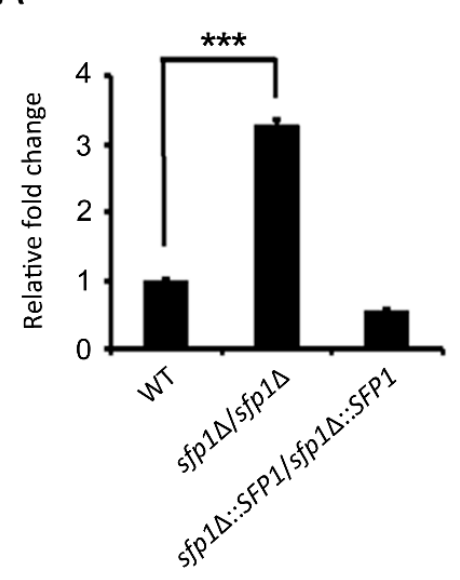

B

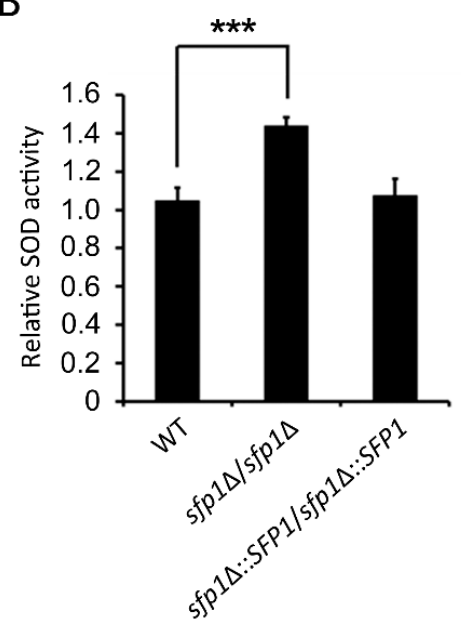

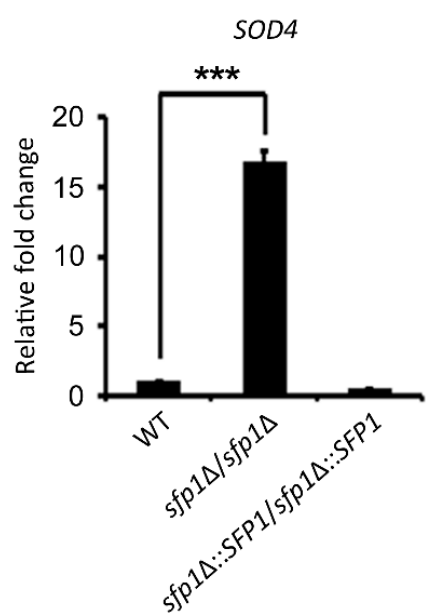

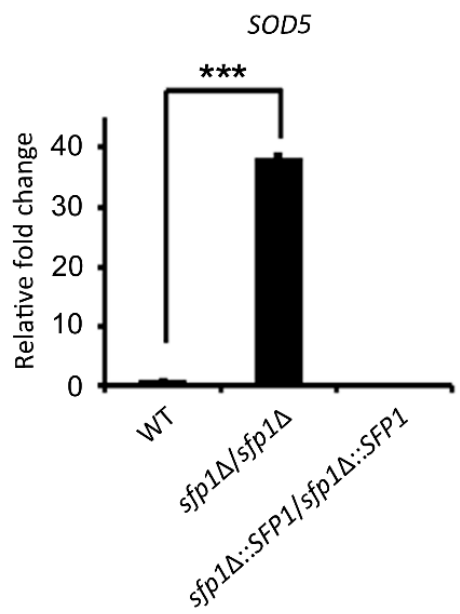

Figure 3. $S O D$ gene expression and activity in cells treated with menadione. (A) The expressions levels of SODs were analyzed using real-time qPCR after treatment of the cells with $170 \mu \mathrm{M}$ menadione for $2 \mathrm{~h}$. The PMA1 transcript was used as an endogenous control. (B) Cells were treated with $170 \mu \mathrm{M}$ menadione for $2 \mathrm{~h}$, and Sod enzyme activity was then measured. The results are presented as the mean \pm standard deviation (SD) of three independent experiments. ${ }^{* * *} P<0.001$.

\subsection{Sfp1 Is Also Related to Cellular Susceptibility to Hydrogen Peroxide}

By the activity of Sods, superoxide is converted into $\mathrm{H}_{2} \mathrm{O}_{2}$. However, $\mathrm{H}_{2} \mathrm{O}_{2}$ is still toxic and highly reactive and requires further detoxification. Therefore, to explore the correlation between Sfp1 and $\mathrm{H}_{2} \mathrm{O}_{2}$ detoxification, cellular susceptibility to $\mathrm{H}_{2} \mathrm{O}_{2}$ was determined through PI staining and flow cytometry. The $s f p 1 \Delta / s f p 1 \Delta$ mutant exhibited a much lower percentage of PI-positive cells after treatment with different concentrations of $\mathrm{H}_{2} \mathrm{O}_{2}$ than the wild-type and SFP1-reintegrated strains (Figure 4A). For example, 55\% of the wild-type cells were PI-positive following $90 \mathrm{mM} \mathrm{H}_{2} \mathrm{O}_{2}$ treatment, whereas only $28 \%$ of the $s f p 1 \Delta / s f p 1 \Delta$ mutant were stained by PI (Figure $4 \mathrm{~A}$ ). 
Moreover, the intracellular ROS content was measured in cells treated with a sublethal dose of $\mathrm{H}_{2} \mathrm{O}_{2}$. The $s f p 1 \Delta / s f p 1 \Delta$ mutant showed significantly lower fluorescence intensity in flow cytometric analysis following $\mathrm{H}_{2}$ DCFDA staining than the wild-type and SFP1-reintegrated strains (Figure 4B). Previous reports indicated that intracellular ROS accumulation is correlated with changes in the $C$. albicans cell surface, leading to a rough appearance with many protrusions and disc-like depressions [36,37]. Similar morphologies were observed when the wild-type strain was treated with $\mathrm{H}_{2} \mathrm{O}_{2}$ (Figure 4C). In contrast, the cell surfaces of the sfp $1 \Delta / s f p 1 \Delta$ mutant $\left( \pm \mathrm{H}_{2} \mathrm{O}_{2}\right)$ and the wild-type (without $\mathrm{H}_{2} \mathrm{O}_{2}$ treatment) remained relatively smooth (Figure 4C). These results are consistent with the low level of intracellular ROS accumulation in the sfp $1 \Delta / s f p 1 \Delta$ strain following $\mathrm{H}_{2} \mathrm{O}_{2}$ treatment (Figure 4B) and suggest that the $s f p 1 \Delta / s f p 1 \Delta$ mutant is better able to detoxify $\mathrm{H}_{2} \mathrm{O}_{2}$ than the wild-type strain.

A

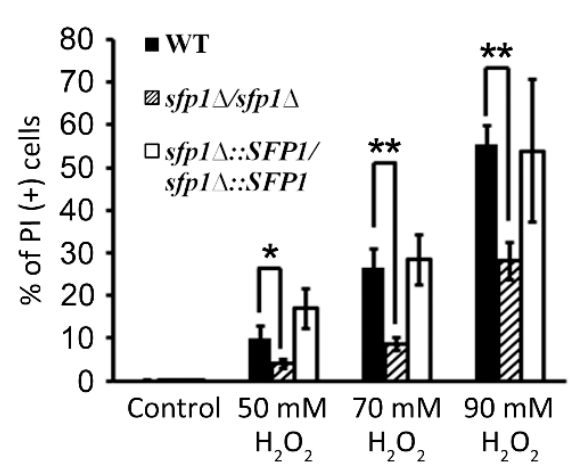

B

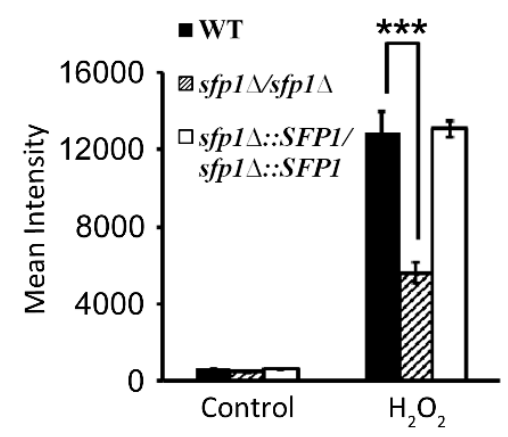

C

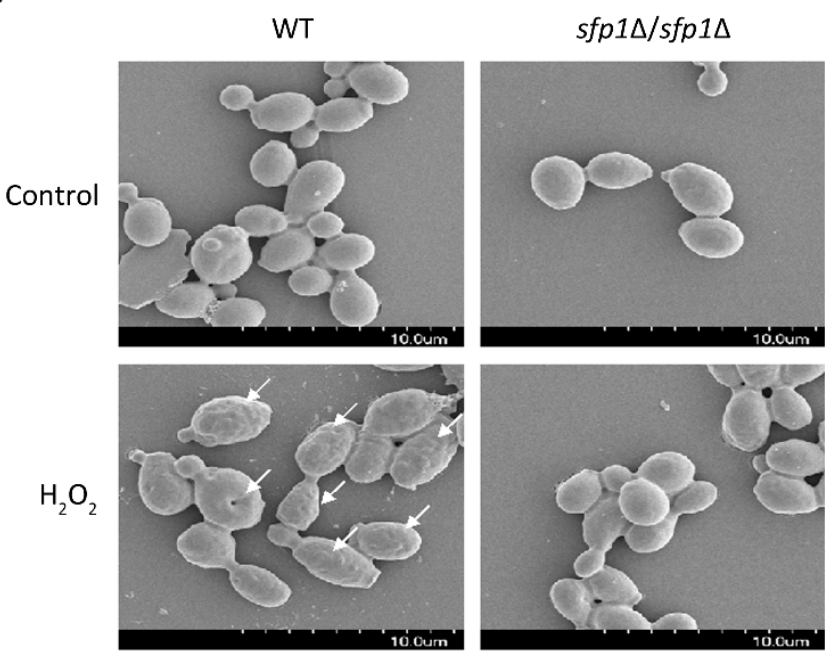

Figure 4. Susceptibility of C. albicans to $\mathrm{H}_{2} \mathrm{O}_{2}$ and $\mathrm{H}_{2} \mathrm{O}_{2}$-induced intracellular $\mathrm{ROS}$ generation. (A) Cells were treated with various concentrations of $\mathrm{H}_{2} \mathrm{O}_{2}$ as indicated for $2 \mathrm{~h}$ and stained with $4 \mu \mathrm{g} / \mathrm{mL}$ PI. Cell viability was then quantified by flow cytometry. The dead cells are represented as PI-positive cells. (B) Cells were treated with $30 \mathrm{mM} \mathrm{H}_{2} \mathrm{O}_{2}$ for $2 \mathrm{~h}$ and stained with $20 \mu \mathrm{g} / \mathrm{mL} \mathrm{H}_{2}$ DCFDA. Intracellular ROS were quantified by flow cytometry. The results are presented as the mean \pm standard deviation (SD) of three independent experiments. ${ }^{* * *} P<0.001$. ${ }^{* *} P<0.01$. ${ }^{*} P<0.05$. (C) Cells were treated with $30 \mathrm{mM} \mathrm{H}_{2} \mathrm{O}_{2}$ for $2 \mathrm{~h}$. Cell surface structure was examined using SEM at 5500× magnification. Arrows point to the rough appearance of protrusions and disc-like depressions. 


\subsection{Sfp1 Regulates the Glutathione System to Detoxify Hydrogen Peroxide}

Both catalase and the glutathione system participate in the conversion of $\mathrm{H}_{2} \mathrm{O}_{2}$ into water $[38,39]$ and provide overlapping defense against $\mathrm{H}_{2} \mathrm{O}_{2}$ in the model yeast Saccharomyces cerevisiae [40]. Therefore, we determined whether the effect of Sfp1 on the cellular response to hydrogen peroxide is via catalase and/or the glutathione system. Interestingly, the $s f p 1 \Delta / s f p 1 \Delta$ mutant displayed slightly lower expression of the CAT1 catalase gene than the wild-type and SFP1-reintegrated strains (Figure 5A). Moreover, catalase enzyme activity was lower in the $s f p 1 \Delta / s f p 1 \Delta$ mutant treated with $\mathrm{H}_{2} \mathrm{O}_{2}$ than in the other tested strains (Figure 5B). However, the $s f p 1 \Delta / s f p 1 \Delta$ mutant showed the upregulation of glutathione-related genes in DNA microarray and real-time qPCR analysis (Table 1 and Figure 6A). These genes included GCS1, GPX2, and GTT11. The GCS1, GPX2, and GTT11 genes encode gamma-glutamylcysteine synthetase, glutathione peroxidase, and glutathione S-transferase, respectively $[20,41,42]$. Therefore, the $s f p 1 \Delta / s f p 1 \Delta$ mutant exhibited lower catalase gene expression and enzyme activity but the increased expression of glutathione redox genes. These results suggest that the resistance to $\mathrm{H}_{2} \mathrm{O}_{2}$ seen in the $s f p 1 \Delta / s f p 1 \Delta$ mutant is mainly due to changes in the glutathione redox system rather than catalase.

To further explore the link between Sfp1 and the glutathione redox system, a sodium selenite sensitivity assay was performed to detect alterations in cellular glutathione content. Glutathione is involved in selenite-induced oxidative stress and reacts with selenite to yield superoxide, causing cell death [43]. Therefore, cells containing a high level of glutathione are more sensitive to sodium selenite. Indeed, Figure $6 \mathrm{~B}$ shows that the $s f p 1 \Delta / s f p 1 \Delta$ mutant was much more sensitive to sodium selenite than the wild-type strain, suggesting a higher cellular glutathione level in the mutant. Moreover, the total glutathione and GSH (reduced form of glutathione) content was also measured. The $s f p 1 \Delta / s f p 1 \Delta$ mutant contained a much higher total glutathione and GHS content than the wild-type and SFP1-reintegrated strains (Figure 6C). Because GSH plays an important role in detoxifying ROS in Candida species [44], the high GSH content likely contributes to $\mathrm{H}_{2} \mathrm{O}_{2}$ resistance in the $s f p 1 \Delta / s f p 1 \Delta$ mutant. Finally, glutathione peroxidases (Gpxs) catalyze the reduction of $\mathrm{H}_{2} \mathrm{O}_{2}$ using GSH, and their activities were measured. As shown in Figure $6 \mathrm{D}$, the $s f p 1 \Delta / s f p 1 \Delta$ mutant possessed much higher Gpx activity than the wild-type and SFP1-reintegrated strains. In summary, the deletion of SFP1 enhanced GCS1, GPX2, and GTT11 gene expression, which was correlated with a higher total glutathione and GSH content and high Gpx activity. These results suggest that Sfp1 is involved in the regulation of the glutathione redox system to detoxify $\mathrm{H}_{2} \mathrm{O}_{2}$.

A

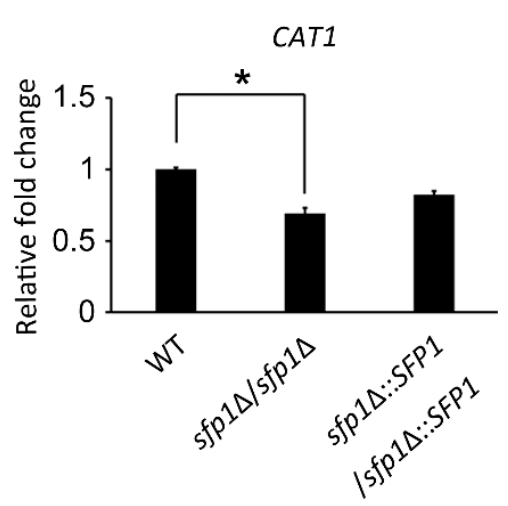

B

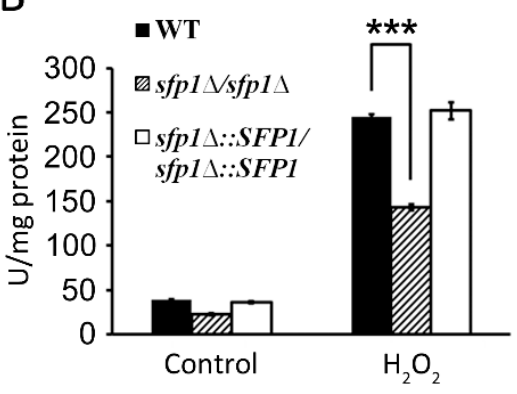

Figure 5. Catalase gene expression and enzyme activity. (A) The expression level of the CAT1 gene was detected using real-time qPCR. The PMA1 transcript was used as an endogenous control. (B) Cells were treated with $1 \mathrm{mM} \mathrm{H}_{2} \mathrm{O}_{2}$ for $2 \mathrm{~h}$, and catalase activity was determined. The results are presented as the mean \pm standard deviation (SD) of three independent experiments. ${ }^{* *} P<0.001$; $^{*} P<0.05$. 
A
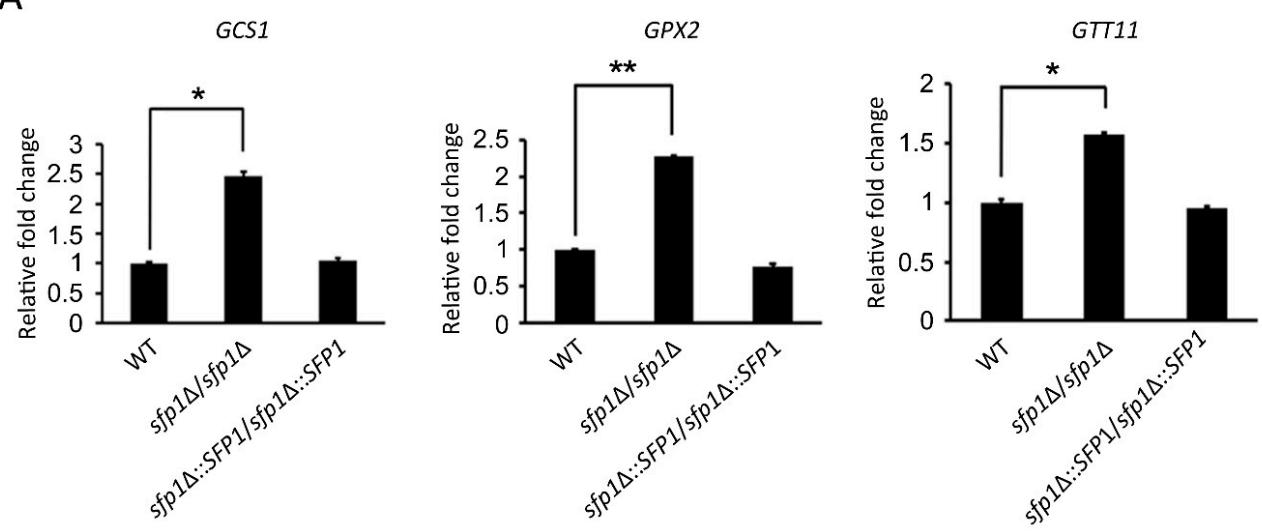

B

SC

Sodium selenite

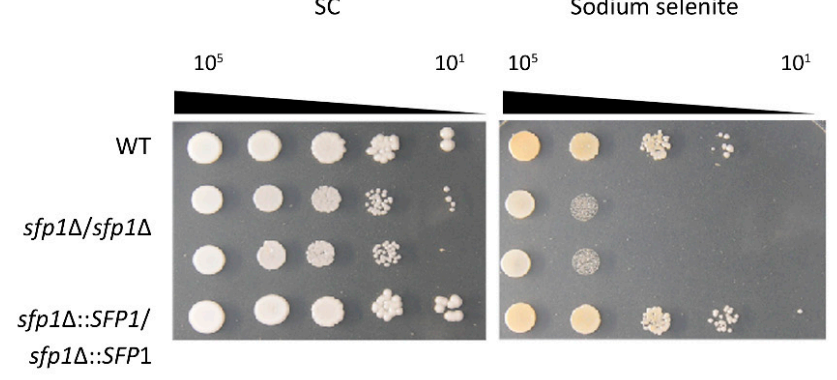

C Total glutathione GSH

D
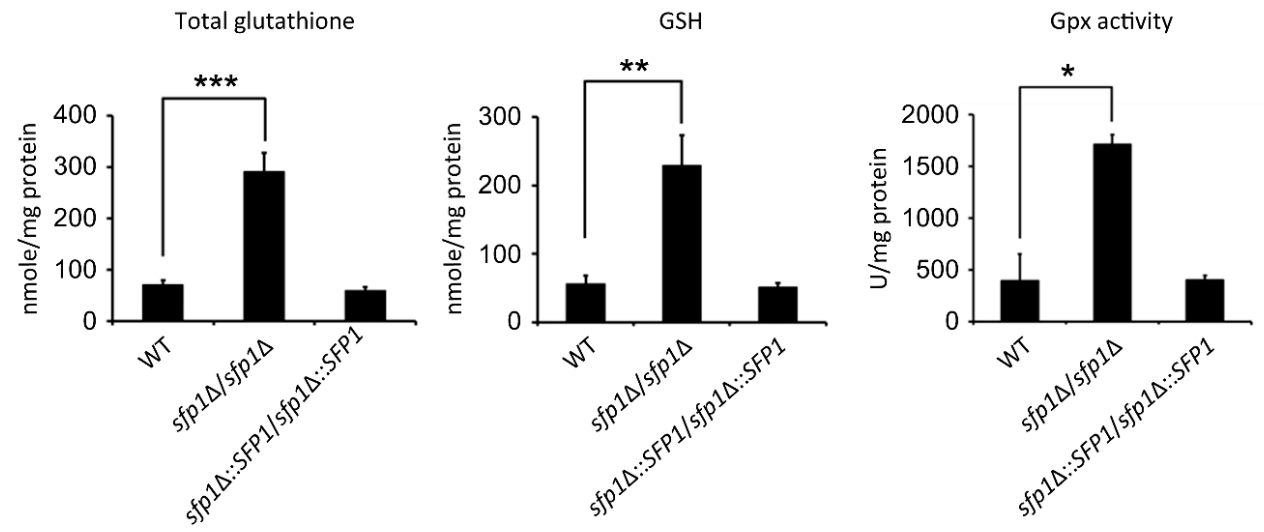

Figure 6. Sfp1 regulates the glutathione system in response to $\mathrm{H}_{2} \mathrm{O}_{2}$. (A) GCS1, GPX2, and GTT11 gene expression levels were detected using real-time qPCR. The PMA1 transcript was used as an endogenous control. The results are presented as the mean \pm standard deviation (SD) of three independent experiments. ${ }^{* *} P<0.01$. ${ }^{*} P<0.05$. (B) One colony was inoculated into YPD medium and grown at $30{ }^{\circ} \mathrm{C}$ overnight. This culture was harvested by centrifugation and washed with sterile double-distilled water $\left(\mathrm{ddH}_{2} \mathrm{O}\right)$. Cells were ten-fold serially diluted and spotted onto YPD agar with or without $3 \mathrm{mM}$ sodium selenite. The agar plates were incubated at $30{ }^{\circ} \mathrm{C}$ for $3-4$ days. Representative images of three independent experiments with identical results are shown. (C) Cells were treated with $1 \mathrm{mM} \mathrm{H}_{2} \mathrm{O}_{2}$ for $2 \mathrm{~h}$. The GSH and GSSG content was determined by measuring TNB absorbance at $415 \mathrm{~nm}$. The GSH content was determined as follows: [total glutathione]-2[GSSG]. The results are presented as the mean \pm standard deviation (SD) of three independent experiments. ${ }^{* *} P<0.01$. ${ }^{* * *} P<0.001$. (D) Cells were treated with $1 \mathrm{mM} \mathrm{H}_{2} \mathrm{O}_{2}$ for $2 \mathrm{~h}$. The enzyme activity of glutathione peroxidase (Gpx) was determined by the oxidation of NADPH. The results are presented as the mean \pm standard deviation (SD) of two independent experiments. ${ }^{*} P<0.05$. 
3.6. The Hog1 Signaling Pathway and the Transcription Factor Cap1 Are Related to the Sfp1-Mediated Oxidative Stress Response

The Hog1 MAPK pathway and Cap1-mediated transcriptional regulation are involved in the C. albicans oxidative stress response. Hog1 phosphorylation and Cap1 are required for the response of C. albicans to oxidants and phagocytic killing $[17,45]$. Based on our results that show Sfp1 is involved in the C. albicans oxidative stress response, we were interested in determining the relationship among Hog1, Cap1, and Sfp1.

As shown by DNA microarray analysis (Table 1) and real-time qPCR (Figure 7A), SSK1 that encodes a component of the Hog1 signaling pathway, was upregulated in the $s f p 1 \Delta / s f p 1 \Delta$ mutant compared to their expression in the other tested strains. In particular, C. albicans utilizes Ssk1 to adapt cells to oxidative stress [32]. As shown by Western blotting in Figure 7B, the $s f p 1 \Delta / s f p 1 \Delta$ mutant contained a significant amount of phosphorylated Hog1 at time point zero, and Hog1 phosphorylation was strongly enhanced in cells treated with $\mathrm{H}_{2} \mathrm{O}_{2}$ for 15 and $30 \mathrm{~min}$ (Figure 7B). However, as shown by a longer exposure of blot, phosphorylated $\mathrm{Hog} 1$ was detected in the wild-type strain in cells treated with $\mathrm{H}_{2} \mathrm{O}_{2}$ (Figure S3). These results suggest that the Sfp1-mediated oxidative stress response involves the Hog1 signaling pathway.

Interestingly, the oxidative stress response genes controlled by Sfp1 (Table 1) overlapped with Cap1, including GCS1, GTT11, YCF1, CYS3, CIP1, EBP1, IFD6, and OYE32 [46,47]. Moreover, the expression of the CAP1 gene was upregulated in the $s f p 1 \triangle / s f p 1 \triangle$ mutant compared to its expression in the wild-type and SFP1-reintegrated strains (Table 1 and Figure 7A). These results raise the possibility that the oxidative stress response of Sfp1 may involve regulating CAP1 expression.

A
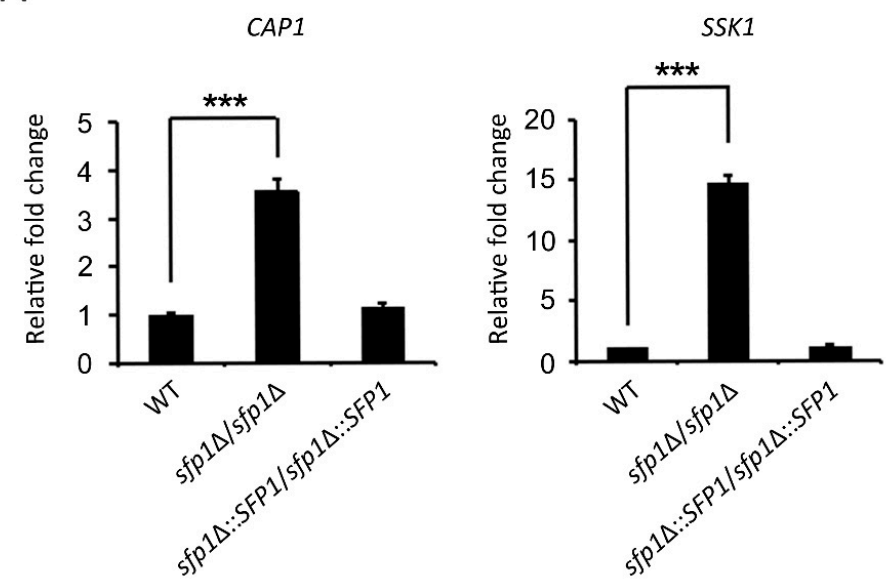

B

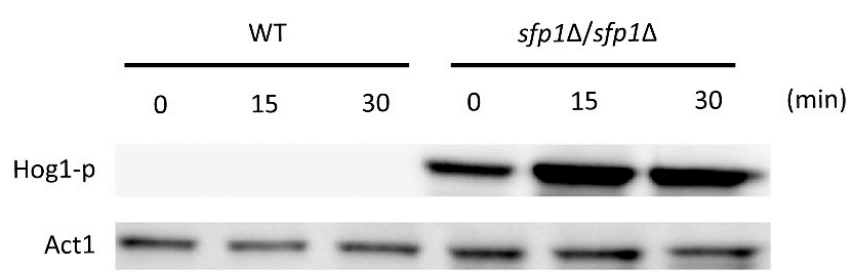

Figure 7. Hog1 signaling and the Cap1 transcription factor are related to the Sfp1-mediated oxidative stress response. (A) Gene expression levels of CAP1 and SSK1 were analyzed using real-time qPCR. The PMA1 transcript was used as an endogenous control. The results are presented as the mean \pm standard deviation (SD) of three independent experiments. ${ }^{* * *} P<0.001$. ${ }^{*} P<0.05$. (B) After cell treatment with $10 \mathrm{mM} \mathrm{H}_{2} \mathrm{O}_{2}$ for 0,15 , and $30 \mathrm{~min}$, Hog1 phosphorylation was assayed using Western blotting. Act1 was used as a loading control. Anti-phospho-p38 (Thr180/Tyr182) antibody (Cell Signaling, Inc.) was used to detect phosphorylated Hog1. Rabbit polyclone anti- $\beta$-actin antibody (GeneTex, Inc.) was used to detect Act1. 


\subsection{The $s f p 1 \Delta / s f p 1 \Delta$ Mutant is Resistant to Macrophage Killing}

During infection, $C$. albicans encounters host phagocytes that produce ROS to kill the pathogen. Due to the involvement of Sfp1 in the oxidative stress response, the interaction between the macrophage cell line RAW264.7 and C. albicans was investigated. There was no statistically significant difference in phagocytosis between the $s f p 1 \triangle / s f p 1 \triangle$ mutant, wild-type, and SFP1-reintegrated strains (Figure $8 \mathrm{~A}$ ). However, the wild type and SFP1-reintegrated strains were relatively sensitive to macrophage killing and displayed $\sim 30 \%$ viability (Figure $8 \mathrm{~B}$ ). In contrast, the $s f p 1 \Delta / s f p 1 \Delta$ mutant was extremely resistant to macrophage killing (Figure $8 \mathrm{~B}$ ). Notably, growth of the $s f p 1 \Delta / s f p 1 \Delta$ mutant was even enhanced in the macrophage.

A

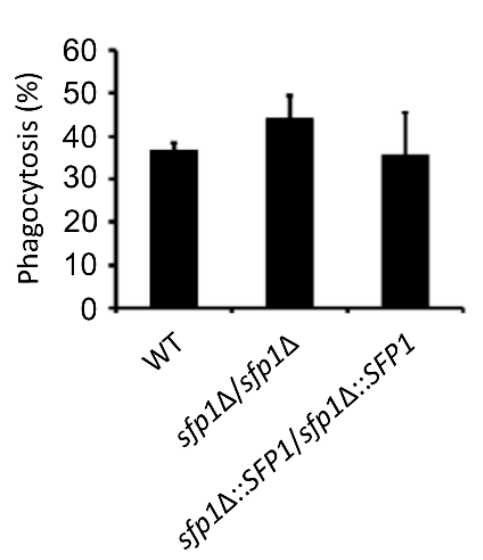

B

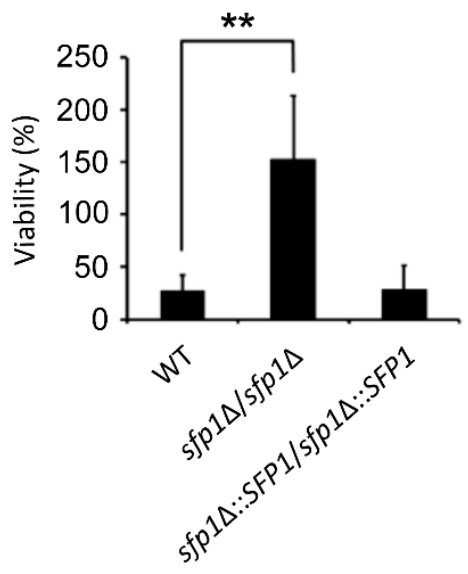

Figure 8. The $s f p 1 \Delta / s f p 1 \Delta$ mutant is resistant to macrophage-mediated killing. (A) C. albicans cells were cocultured with $2 \times 10^{6}$ macrophage cells for $20 \mathrm{~min}$ at an MOI of 1 . Data were obtained from three independent experiments by analyzing at least 300 macrophages per well. (B) A total of $10^{5} \mathrm{C}$. albicans cells were cocultured with macrophages for $16 \mathrm{~h}$ at an MOI of 1:10. The cell viability was determined by CFU counting. The results are presented as the mean \pm standard deviation (SD) of five independent experiments. ${ }^{* *} P<0.01$.

\subsection{The sfp1 $1 \Delta / s f p 1 \Delta$ Mutant is Resistant to ROS-Generating Antifungals}

Miconazole and caspofungin are commonly used antifungals that induce ROS to kill C. albicans $[7,8]$. In addition, the addition of antioxidants impairs ROS-generating antifungal efficacy $[7,21]$. Because the $s f p 1 \Delta / s f p 1 \Delta$ mutant exhibits high antioxidative activity, we were interested in linking the susceptibility of the $s f p 1 \Delta / s f p 1 \Delta$ mutant to ROS-generating antifungals. As shown in Figure 9A, the result of spot assay showed that the $s f p 1 \Delta / s f p 1 \Delta$ mutant was resistant to miconazole and caspofungin, as opposed to the controls. Moreover, $\mathrm{H}_{2}$ DCFDA staining was performed to measure the intracellular ROS content upon antifungal drug treatment. The $s f p 1 \Delta / s f p 1 \Delta$ mutant exhibited less ROS accumulation with miconazole and caspofungin treatment than the controls (Figure 9B). 

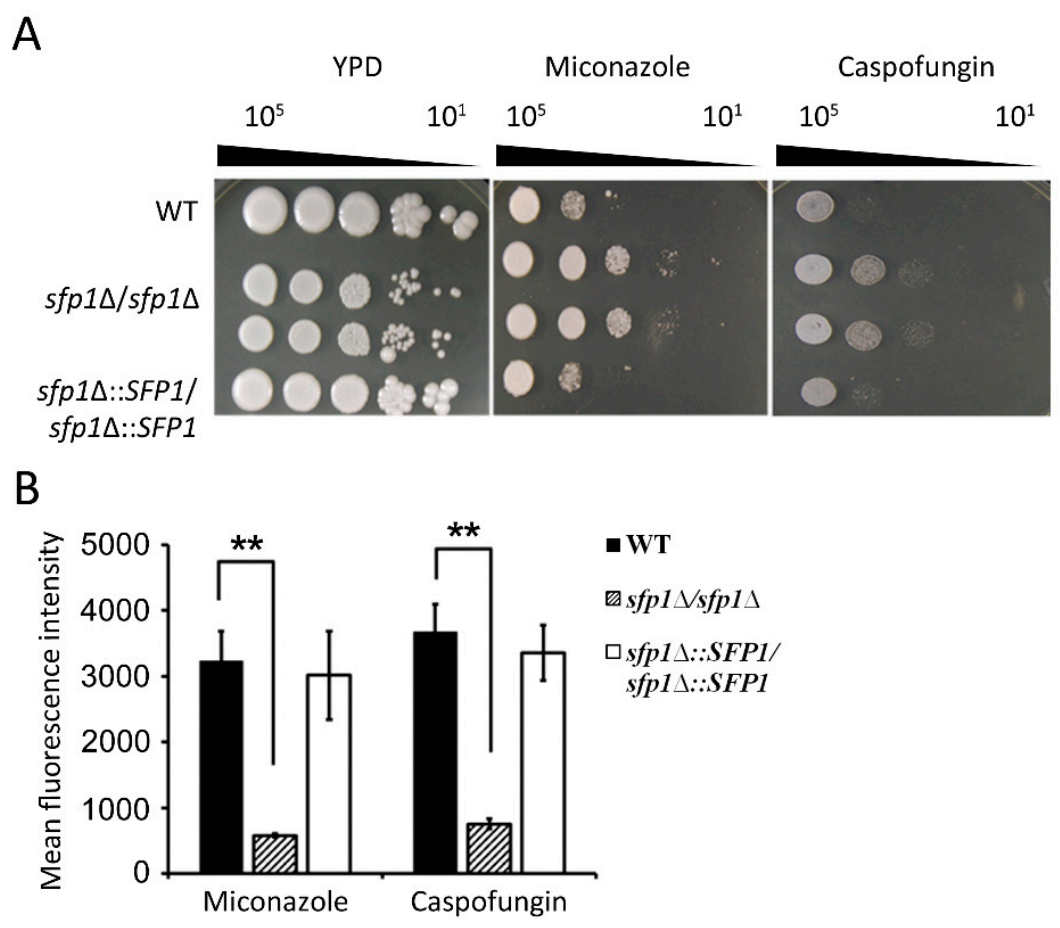

Figure 9. The effect of SFP1 deletion on cellular susceptibility to ROS-generating antifungals and the accumulation of intracellular ROS upon antifungal treatment. (A) One colony was inoculated into YPD medium and grown at $30{ }^{\circ} \mathrm{C}$ overnight. This culture was harvested by centrifugation and washed with sterile double-distilled water $\left(\mathrm{ddH}_{2} \mathrm{O}\right)$. Cells were ten-fold serially diluted and spotted onto YPD agar with or without $8 \mu \mathrm{g} / \mathrm{mL}$ of an antifungal. The agar plates were incubated at $30{ }^{\circ} \mathrm{C}$ for 3-4 days. Representative images of three independent experiments with identical results are shown. (B) Cells were treated with $3 \mu \mathrm{g} / \mathrm{mL}$ miconazole or $1 \mu \mathrm{g} / \mathrm{mL}$ caspofungin for $2 \mathrm{~h}$. Intracellular ROS were measured using $\mathrm{H}_{2}$ DCFDA staining and quantified by a flow cytometer. The results are presented as the mean \pm standard deviation (SD) of three independent experiments. ${ }^{* *} P<0.01$.

\section{Discussion}

C. albicans is challenged by oxidative stress from host phagocytes and antifungals [3,4]. C. albicans has complex antioxidant systems, signaling pathways, and transcriptional regulatory machinery to cope with oxidative stress. One key mechanism known to activate the expression of antioxidant genes is primarily mediated by Cap1, a bZIP transcription factor in the AP-1 family [47,48]. After exposure to $\mathrm{H}_{2} \mathrm{O}_{2}$, Cap1 is activated by the oxidation of its redox-active cysteine residues, allowing the nuclear accumulation of Cap1 [21]. Within the nucleus, Cap1 is phosphorylated and induces the expression of many genes, including CAT1, which encodes catalase, and TRX1, which encodes thioredoxin [46]. Moreover, C. albicans cells lacking CAP1 are sensitive to ROS and phagocyte killing [34,49]. Another mechanism related to the $C$. albicans oxidative response is Hog1 MAPK signaling [50]. Hog1 is activated in C. albicans in response to diverse stimuli, such as high doses of $\mathrm{H}_{2} \mathrm{O}_{2}$, which results in its nuclear accumulation [14]. Moreover, global transcriptional analysis using DNA microarray revealed that 46 core stress genes induced in response to $\mathrm{H}_{2} \mathrm{O}_{2}$ are Hog1-dependent [51].

In this study, we demonstrated that the transcription factor Sfp1 is also involved in the oxidative stress response of $C$. albicans. We showed that the $s f p 1 \Delta / s f p 1 \Delta$ mutant possesses a higher total antioxidant capacity, Sod enzyme activity, GSH content, and glutathione peroxidase activity than the wild-type and SFP1-reintegrated strains (Figure 1, Figure 3, and Figure 6). In addition, the sfp $1 \Delta / s f p 1 \Delta$ mutant was more resistant to phagocyte killing and ROS-inducing antifungals (Figures 8 and 9). Moreover, DNA microarray analysis and real-time qPCR revealed that the expression of many oxidative stress response-related genes was upregulated in the $s f p 1 \Delta / s f p 1 \Delta$ mutant compared to their expression in the other two strains, including CAP1 (Table 1 and Figure 7A). Moreover, many oxidative stress response 
genes (e.g., SOD1, GCS1, GTT11, CIP1, EBP1, IFD6, and OYE32) were regulated by both Sfp1 and Cap1 [[46,47] and Table 1]. Recently, Sfp1 was found to reciprocally modulate carbon source-conditional stress adaptation with another transcription factor, Rtg3 [52]. Sfp1 regulates oxidative stress response genes in a carbon source-dependent manner [52]. In the study of Kastora et al. [52], the sfp1 $/ s f p 1 \Delta$ mutant was more sensitive to $\mathrm{H}_{2} \mathrm{O}_{2}$ than the wild-type strain. These results contrasted with the increased sensitivity of the $s f p 1 \Delta / s f p 1 \Delta$ mutant to $\mathrm{H}_{2} \mathrm{O}_{2}$ in this study (Figure 1). Our explanation for this result is that these two studies use $C$. albicans strains from a different genetic background and different concentrations of $\mathrm{H}_{2} \mathrm{O}_{2}$. Taken together, our and other studies highlight the complex transcription regulation network of the oxidative stress response. However, the epistatic relationship between Sfp1, Rtg3, and Cap1 needs to be further investigated by either construction of a double mutant or chromatin immunoprecipitation to determine the possible interaction between the Sfp1 protein and the CAP1 promoter. Additionally, whether Sfp1 directly controls oxidative stress genes also requires further study.

In addition to Cap1, Sfp1 is also associated with the Hog1 MAPK signaling pathway. As shown in Figure 7A, the $s f p 1 \Delta / s f p 1 \Delta$ mutant exhibited increased gene expression of the response regulator SSK1, which is an upstream component of the Hog1 cascade, compared to its expression in the other tested strains [53]. In particular, Ssk1 is required for oxidative stress response [32,54], phagocyte killing, and virulence in a disseminate murine model of candidiasis [55,56]. Moreover, Hog1 phosphorylation was enhanced in the $s f p 1 \Delta / s f p 1 \Delta$ mutant compared to that in the wild-type strain in the absence and presence of $\mathrm{H}_{2} \mathrm{O}_{2}$ (Figure 7). Finally, compared to the catalase Cat1, the glutathione system seems to play a greater role in $\mathrm{H}_{2} \mathrm{O}_{2}$ detoxification in the sfp $1 \Delta / s f p 1 \Delta$ mutant (Figures 5 and 6). Glutathione is the most important thiol-containing molecule required to maintain the redox homeostasis, as it functions as redox buffer, antioxidant, and enzyme cofactor against oxidative stress [57-59]. Interestingly, the $s f p 1 \Delta / s f p 1 \Delta$ mutant exhibited the upregulation of the MET1 and CYS3 genes (Table 1), which encode enzymes involved in methionine and cysteine biosynthesis, respectively. Methionine and cysteine are the precursors of glutathione biosynthesis [42]. Recently, the relationship between Hog1 and Sfp1 was revealed, in which Hog1 is required for Sfp1-dependent ribosome biogenesis (RiBi) gene expression and recruitment to target promoters [60]. However, future studies to examine the role of Hog1 and Sfp1 in C. albicans amino acid and glutathione biosynthesis are still needed.

In addition to $C$. albicans, transcription factors that are vital for controlling oxidative stress response have been also studied in other fungal species [61-64]. For example, Skn7 and Yap1 are the AP-1-like bZIP transcription factors in S. cerevisiae. Yap1 is the orthologue of C. albicans Cap1 and accumulates in the nucleus following exposure to $\mathrm{H}_{2} \mathrm{O}_{2}$ [62]. Previous studies indicated that Yap1 collaborates with Skn7 to control many oxidative stress response genes [62,65-67]. Similarly, Candida glabrata Yap1 and $\mathrm{Skn} 7$ are involved in oxidative stress response by cooperatively binding to the upstream region of core oxidative stress genes [68]. Moreover, Ada2 is suggested to orchestrate C. glabrata against ROS-mediated immune defenses during infection [69]. Evidence for Skn7 having a role in virulence is also reported in different fungal species [70]. Therefore, oxidative stress adaptation is not only essential for cell survival, but also an important virulence trait. In this study, our results showed the multiple functions of Sfp1 and the regulatory complexity of the C. albicans oxidative stress response. These results should also provide useful insight into the oxidative stress response in other important human fungal pathogens.

Supplementary Materials: The following are available online at http://www.mdpi.com/2076-2607/7/5/131/s1. Table S1: The C. albicans strains used in this study, Table S2: Oligonucleotides used in this study, Figure S1: Gene ontology (GO) distribution of C. albicans genes regulated by Sfp1. Figure S2: The SOD2 and SOD3 gene expression in the $s f p 1 \Delta / s f p 1 \Delta$ mutant. Figure S3. Hog1 phosphorylation by Western blot with a longer exposure.

Author Contributions: Conceptualization, S.-Y.L., H.-F.C., and C.Y.L.; methodology, S.-Y.L., H.-F.C., Y.-P.X., and C.-Y.L.; validation, S.-Y.L. and H.-F.C.; formal analysis, S.-Y.L. and H.-F.C.; investigation, S.-Y.L. and H.-F.C.; resources, H.-F.C., Y.-C.Y., Y.-P.X., and C.-Y.L.; data curation, S.-Y.L. and H.-F.C.; writing-original draft preparation, S.-Y.L., C.-Y.L.; writing-review and editing, H.-F.C., Y.-C.Y., Y.-P.X., and C.-Y.L.; visualization, S.-Y.L., H.-F.C., Y.-C.Y., and C.-Y.L.; supervision, C.-Y.L., project administration, C.-Y.L., funding acquisition, C.-Y.L. 
Funding: This research was funded by the Ministry of Science and Technology (Taiwan, ROC), grant number MOST105-2311-B-007-007-MY3.

Conflicts of Interest: The authors declare no conflict of interest.

\section{References}

1. Odd, F. Candida and Candidiasis: A Review and Bibliography; Bailliere Tindal: London, UK, 1988.

2. Arendrup, M.C.; Patterson, T.F. Multidrug-resistant Candida: Epidemiology, molecular mechanisms, and treatment. J. Infect. Dis. 2017, 216, S445-S451. [CrossRef]

3. Dantas Ada, S.; Day, A.; Ikeh, M.; Kos, I.; Achan, B.; Quinn, J. Oxidative stress responses in the human fungal pathogen, Candida albicans. Biomolecules 2015, 5, 142-165. [CrossRef] [PubMed]

4. Delattin, N.; Cammue, B.P.; Thevissen, K. Reactive oxygen species-inducing antifungal agents and their activity against fungal biofilms. Future Med. Chem. 2014, 6, 77-90. [CrossRef]

5. Kaloriti, D.; Tillmann, A.; Cook, E.; Jacobsen, M.; You, T.; Lenardon, M.; Ames, L.; Barahona, M.; Chandrasekaran, K.; Coghill, G.; et al. Combinatorial stresses kill pathogenic Candida species. Med. Mycol. 2012, 50, 699-709. [CrossRef] [PubMed]

6. Mesa-Arango, A.C.; Trevijano-Contador, N.; Roman, E.; Sanchez-Fresneda, R.; Casas, C.; Herrero, E.; Arguelles, J.C.; Pla, J.; Cuenca-Estrella, M.; Zaragoza, O. The production of reactive oxygen species is a universal action mechanism of amphotericin B against pathogenic yeasts and contributes to the fungicidal effect of this drug. Antimicrob. Agents Chemother. 2014, 58, 6627-6638. [CrossRef] [PubMed]

7. Kobayashi, D.; Kondo, K.; Uehara, N.; Otokozawa, S.; Tsuji, N.; Yagihashi, A.; Watanabe, N. Endogenous reactive oxygen species Is an important mediator of miconazole antifungal effect. Antimicrob. Agents Chemother. 2002, 46, 3113-3117. [CrossRef]

8. Hao, B.; Cheng, S.; Clancy, C.J.; Nguyen, H.M. Caspofungin kills Candida albicans by causing both cellular apoptosis and necrosis. Antimicrob. Agents Chemother. 2012, 57, 326-332. [CrossRef]

9. Bink, A.; Vandenbosch, D.; Coenye, T.; Nelis, H.; Cammue, B.P.A.; Thevissen, K. Superoxide dismutases are involved in Candida albicans biofilm persistence against miconazole. Antimicrob. Agents Chemother. 2011, 55, 4033-4037. [CrossRef]

10. Brucker, K.; Bink, A.; Meert, E.; Cammue, B.P.A.; Thevissen, K. Potentiation of antibiofilm activity of amphotericin B by superoxide dismutase inhibition. Oxid. Med. Cell. Longev. 2013, 2013, 1-7. [CrossRef]

11. Komalapriya, C.; Kaloriti, D.; Tillmann, A.T.; Yin, Z.; Herrero-de-Dios, C.; Jacobsen, M.D.; Belmonte, R.C.; Cameron, G.; Haynes, K.; Grebogi, C.; et al. Integrative model of oxidative stress adaptation in the fungal pathogen Candida albicans. PLoS ONE 2015, 10, e0137750. [CrossRef] [PubMed]

12. Broxton, C.N.; Culotta, V.C. SOD enzymes and microbial pathogens: Surviving the oxidative storm of infection. PLoS Pathog. 2016, 12, e1005295. [CrossRef]

13. Wysong, D.R.; Christin, L.; Sugar, A.M.; Robbins, P.W.; Diamond, R.D. Cloning and sequencing of a Candida albicans catalase gene and effects of disruption of this gene. Infect. Immun. 1998, 66, 1953-1961.

14. Smith, D.A.; Nicholls, S.; Morgan, B.A.; Brown, A.J.; Quinn, J. A conserved stress-activated protein kinase regulates a core stress response in the human pathogen Candida albicans. Mol. Biol. Cell 2004, 15, 4179-4190. [CrossRef]

15. Arana, D.M.; Alonso-Monge, R.; Du, C.; Calderone, R.; Pla, J. Differential susceptibility of mitogen-activated protein kinase pathway mutants to oxidative-mediated killing by phagocytes in the fungal pathogen Candida albicans. Cell. Microbiol. 2007, 9, 1647-1659. [CrossRef] [PubMed]

16. Alonso-Monge, R.; Navarro-Garcia, F.; Molero, G.; Diez-Orejas, R.; Gustin, M.; Pla, J.; Sanchez, M.; Nombela, C. Role of the mitogen-activated protein kinase Hog1p in morphogenesis and virulence of Candida albicans. J. Bacteriol. 1999, 181, 3058-3068.

17. Patterson, M.J.; McKenzie, C.G.; Smith, D.A.; da Silva Dantas, A.; Sherston, S.; Veal, E.A.; Morgan, B.A.; MacCallum, D.M.; Erwig, L.-P.P.; Quinn, J. Ybp1 and Gpx3 signaling in Candida albicans govern hydrogen peroxide-induced oxidation of the Cap1 transcription factor and macrophage escape. Antioxid. Redox Signal. 2013, 19, 2244-2260. [CrossRef]

18. Hwang, C.-S.S.; Rhie, G.-e.E.; Oh, J.-H.H.; Huh, W.-K.K.; Yim, H.-S.S.; Kang, S.-O.O. Copper- and zinc-containing superoxide dismutase $(\mathrm{Cu} / \mathrm{ZnSOD})$ is required for the protection of Candida albicans against oxidative stresses and the expression of its full virulence. Microbiology 2002, 148, 3705-3713. [CrossRef] 
19. Frohner, I.E.; Bourgeois, C.; Yatsyk, K.; Majer, O.; Kuchler, K. Candida albicans cell surface superoxide dismutases degrade host-derived reactive oxygen species to escape innate immune surveillance. Mol. Microbiol. 2009, 71, 240-252. [CrossRef] [PubMed]

20. Miramón, P.; Dunker, C.; Kasper, L.; Jacobsen, I.D.; Barz, D.; Kurzai, O.; Hube, B. A family of glutathione peroxidases contributes to oxidative stress resistance in Candida albicans. Med. Mycol. 2014, 52, 223-239. [CrossRef] [PubMed]

21. Roman, E.; Prieto, D.; Martin, R.; Correia, I.; Mesa Arango, A.C.; Alonso-Monge, R.; Zaragoza, O.; Pla, J. Role of catalase overproduction in drug resistance and virulence in Candida albicans. Future Microbiol. 2016. [CrossRef] [PubMed]

22. Chen, H.-F.; Lan, C.-Y. Role of SFP1 in the regulation of Candida albicans biofilm formation. PLoS ONE 2015, 10, e0129903. [CrossRef]

23. Hsu, P.C.; Chao, C.C.; Yang, C.Y.; Ye, Y.L.; Liu, F.C.; Chuang, Y.J.; Lan, C.Y. Diverse Hap43-independent functions of the Candida albicans CCAAT-binding complex. Eukaryot. Cell 2013, 12, 804-815. [CrossRef] [PubMed]

24. Nailis, H.; Coenye, T.; Van Nieuwerburgh, F.; Deforce, D.; Nelis, H.J. Development and evaluation of different normalization strategies for gene expression studies in Candida albicans biofilms by real-time PCR. BMC Mol. Biol. 2006, 7, 25. [CrossRef]

25. Livak, K.J.; Schmittgen, T.D. Analysis of relative gene expression data using real-time quantitative PCR and the 2(-Delta Delta C(T)) Method. Methods 2001, 25, 402-408. [CrossRef]

26. Yu, Q.; Zhang, B.; Li, J.; Zhang, B.; Wang, H.; Li, M. Endoplasmic reticulum-derived reactive oxygen species (ROS) is involved in toxicity of cell wall stress to Candida albicans. Free Radic. Biol. Med. 2016, 99, 572-583. [CrossRef]

27. Dai, B.-D.D.; Wang, Y.; Zhao, L.-X.X.; Li, D.-D.D.; Li, M.-B.B.; Cao, Y.-B.B.; Jiang, Y.-Y.Y. Cap1p attenuates the apoptosis of Candida albicans. FEBS J. 2013, 280, 2633-2643. [CrossRef]

28. Beers, R.F.; Sizer, I.W. A spectrophotometric method for measuring the breakdown of hydrogen peroxide by catalase. J. Biol. Chem. 1952, 195, 133-140. [PubMed]

29. Rahman, I.; Kode, A.; Biswas, S.K. Assay for quantitative determination of glutathione and glutathione disulfide levels using enzymatic recycling method. Nat. Protoc. 2006, 1, 3159-3165. [CrossRef]

30. Maras, B.; Angiolella, L.; Mignogna, G.; Vavala, E.; Macone, A.; Colone, M.; Pitari, G.; Stringaro, A.; Dupré, S.; Palamara, A.T. Glutathione metabolism in Candida albicans resistant strains to fluconazole and micafungin. PLoS ONE 2014, 9, e98387. [CrossRef]

31. Tsao, C.C.; Chen, Y.T.; Lan, C.Y. A small G protein Rhb1 and a GTPase-activating protein Tsc2 involved in nitrogen starvation-induced morphogenesis and cell wall integrity of Candida albicans. Fungal Genet. Biol. 2009, 46, 126-136. [CrossRef]

32. Chauhan, N.; Inglis, D.; Roman, E.; Pla, J.; Li, D.; Calera, J.A.; Calderone, R. Candida albicans response regulator gene SSK1 regulates a subset of genes whose functions are associated with cell wall biosynthesis and adaptation to oxidative stress. Eukaryot. Cell 2003, 2, 1018-1024. [CrossRef]

33. Wang, Y.; Cao, Y.Y.; Jia, X.M.; Cao, Y.B.; Gao, P.H.; Fu, X.P.; Ying, K.; Chen, W.S.; Jiang, Y.Y. Cap1p is involved in multiple pathways of oxidative stress response in Candida albicans. Free Radic. Biol. Med. 2006, 40, 1201-1209. [CrossRef] [PubMed]

34. Zhang, X.; De Micheli, M.; Coleman, S.T.; Sanglard, D.; Moye-Rowley, W.S. Analysis of the oxidative stress regulation of the Candida albicans transcription factor, Cap1p. Mol. Microbiol. 2000, 36, 618-629. [CrossRef] [PubMed]

35. Missall, T.A.; Lodge, J.K.; McEwen, J.E. Mechanisms of resistance to oxidative and nitrosative stress: Implications for fungal survival in mammalian hosts. Eukaryot. Cell 2004, 3, 835-846. [CrossRef] [PubMed]

36. Lin, G.-Y.; Chen, H.-F.; Xue, Y.-P.; Yeh, Y.-C.; Chen, C.-L.; Liu, M.-S.; Cheng, W.-C.; Lan, C.-Y. The Antimicrobial Peptides P-113Du and P-113Tri Function against Candida albicans. Antimicrob. Agents Chemother. 2016, 60, 6369-6373. [CrossRef]

37. Ramírez-Quijas, M.D.; Zazueta-Sandoval, R. Effect of oxidative stress on cell wall morphology in four pathogenic Candida species. Mycol. Prog. 2015, 14, 8. [CrossRef]

38. Nakagawa, Y.; Koide, K.; Watanabe, K.; Morita, Y.; Mizuguchi, I.; Akashi, T. The expression of the pathogenic yeast Candida albicans catalase gene in response to hydrogen peroxide. Microbiol. Immunol. 1999, 43, 645-651. [CrossRef] [PubMed] 
39. Quintana-Cabrera, R.; Bolanos, J.P. Glutathione and gamma-glutamylcysteine in hydrogen peroxide detoxification. Methods Enzymol. 2013, 527, 129-144. [CrossRef]

40. Grant, C.M.; Perrone, G.; Dawes, I.W. Glutathione and catalase provide overlapping defenses for protection against hydrogen peroxide in the yeast Sacharomyces cerevisiae. Biochem. Biophys. Res. Commun. 1998, 253, 893-898. [CrossRef]

41. Garcerá, A.; Casas, C.; Herrero, E. Expression of Candida albicans glutathione transferases is induced inside phagocytes and upon diverse environmental stresses. FEMS Yeast Res. 2010, 10, 422-431. [CrossRef]

42. Yadav, A.K.; Desai, P.R.; Rai, M.N.; Kaur, R.; Ganesan, K.; Bachhawat, A.K. Glutathione biosynthesis in the yeast pathogens Candida glabrata and Candida albicans: Essential in C. glabrata, and essential for virulence in C. albicans. Microbiology 2011, 157, 484-495. [CrossRef]

43. Chen, J.J.; Boylan, L.M.; Wu, C.K.; Spallholz, J.E. Oxidation of glutathione and superoxide generation by inorganic and organic selenium compounds. Biofactors 2007, 31, 55-66. [CrossRef] [PubMed]

44. Gutierrez-Escobedo, G.; Orta-Zavalza, E.; Castano, I.; De Las Penas, A. Role of glutathione in the oxidative stress response in the fungal pathogen Candida glabrata. Curr. Genet. 2013, 59, 91-106. [CrossRef]

45. Alonso-Monge, R.; Navarro-García, F.; Román, E.; Negredo, A.I.; Eisman, B.; Nombela, C.; Pla, J. The Hog1 mitogen-activated protein kinase is essential in the oxidative stress response and chlamydospore formation in Candida albicans. Eukaryot. Cell 2003, 2, 351-361. [CrossRef] [PubMed]

46. Znaidi, S.; Barker, K.S.; Weber, S.; Alarco, A.M.; Liu, T.T.; Boucher, G.; Rogers, P.D.; Raymond, M. Identification of the Candida albicans Cap1p regulon. Eukaryot. Cell 2009, 8, 806-820. [CrossRef]

47. Moye-Rowley, W.S. Regulation of the transcriptional response to oxidative stress in fungi: Similarities and differences. Eukaryot. Cell 2003, 2, 381-389. [CrossRef] [PubMed]

48. Kos, I.; Patterson, M.J.; Znaidi, S.; Kaloriti, D.; da Silva Dantas, A.; Herrero-de-Dios, C.M.; d’Enfert, C.; Brown, A.J.; Quinn, J. Mechanisms underlying the delayed activation of the Cap1 transcription factor in Candida albicans following combinatorial oxidative and cationic stress important for phagocytic potency. mBio 2016, 7, e00331. [CrossRef]

49. Jimenez-Lopez, C.; Lorenz, M.C. Fungal immune evasion in a model host-pathogen interaction: Candida albicans versus macrophages. PLoS Pathog. 2013, 9, e1003741. [CrossRef] [PubMed]

50. Smith, D.A.; Morgan, B.A.; Quinn, J. Stress signalling to fungal stress-activated protein kinase pathways. FEMS Microbiol. Lett. 2010, 306, 1-8. [CrossRef]

51. Enjalbert, B.; Smith, D.A.; Cornell, M.J.; Alam, I.; Nicholls, S.; Brown, A.J.; Quinn, J. Role of the Hog1 stress-activated protein kinase in the global transcriptional response to stress in the fungal pathogen Candida albicans. Mol. Biol. Cell 2006, 17, 1018-1032. [CrossRef]

52. Kastora, S.L.; Herrero-de-Dios, C.; Avelar, G.M.; Munro, C.A.; Brown, A.J.P. Sfp1 and Rtg3 reciprocally modulate carbon source-conditional stress adaptation in the pathogenic yeast Candida albicans. Mol. Microbiol. 2017, 105, 620-636. [CrossRef] [PubMed]

53. Monge, R.A.; Roman, E.; Nombela, C.; Pla, J. The MAP kinase signal transduction network in Candida albicans. Microbiology 2006, 152, 905-912. [CrossRef]

54. Menon, V.; De Bernardis, F.; Calderone, R.; Chauhan, N. Transcriptional profiling of the Candida albicans Ssk1p receiver domain point mutants and their virulence. FEMS Yeast Res. 2008, 8, 756-763. [CrossRef]

55. Calera, J.A.; Zhao, X.J.; Calderone, R. Defective hyphal development and avirulence caused by a deletion of the SSK1 response regulator gene in Candida albicans. Infect. Immun. 2000, 68, 518-525. [CrossRef] [PubMed]

56. Du, C.; Calderone, R.; Richert, J.; Li, D. Deletion of the SSK1 response regulator gene in Candida albicans contributes to enhanced killing by human polymorphonuclear neutrophils. Infect. Immun. 2005, 73, 865-871. [CrossRef] [PubMed]

57. Grant, C.M.; Maclver, F.H.; Dawes, I.W. Glutathione is an essential metabolite required for resistance to oxidative stress in the yeast Saccharomyces cerevisiae. Curr. Genet. 1996, 29, 511-515. [CrossRef]

58. Meister, A.; Anderson, M.E. Glutathione. Annu. Rev. Biochem. 1983, 52, 711-760. [CrossRef]

59. Tillmann, A.T.; Strijbis, S.; Cameron, G.; Radmaneshfar, E.; Thiel, M.; Munro, C.A.; MacCallum, D.M.; Distel, B.; Gow, N.A.R.; Brown, A.J.P. Contribution of Fdh3 and Glr1 to glutathione redox state, stress adaptation and virulence in Candida albicans. PLoS ONE 2015, 10, e0126940. [CrossRef]

60. Sellam, A.; Charillot, J.; Mallick, J.; Tebbji, F.; Richard, J.; Michael, A.; Cook, M.; Tyers, M. The p38/HOG stress-activated protein kinase network couples growth to division in Candida albicans. PLoS Genet. 2019, 15, e1008052. [CrossRef] 
61. Brown, A.J.P.; Cowen, L.E.; di Pietro, A.; Quinn, J. Stress adaptation. Microbiol. Spectr. 2017, 5, 66-75. [CrossRef]

62. Morano, K.A.; Grant, C.M.; Moye-Rowley, W.S. The response to heat shock and oxidative stress in Saccharomyces cerevisiae. Genetics 2012, 190, 1157-1195. [CrossRef] [PubMed]

63. Roetzer, A.; Gregori, C.; Jennings, A.M.; Quintin, J.; Ferrandon, D.; Butler, G.; Kuchler, K.; Ammerer, G.; Schuller, C. Candida glabrata environmental stress response involves Saccharomyces cerevisiae Msn2/4 orthologous transcription factors. Mol. Microbiol. 2008, 69, 603-620. [CrossRef] [PubMed]

64. Zhao, H.; Chen, J.; Liua, J.; Han, B. A transcriptome analysis reveals the oxidative stress response in Saccharomyces cerevisiae. RSC. Adv. 2015, 5, 22923-22934. [CrossRef]

65. Charizanis, C.; Juhnke, H.; Krems, B.; Entian, K.D. The oxidative stress response mediated via Pos9/Skn7 is negatively regulated by the Ras/PKA pathway in Saccharomyces cerevisiae. Mol. Gen. Genet. 1999, 261, 740-752. [CrossRef]

66. Gomez-Pastor, R.; Garre, E.; Perez-Torrado, R.; Matallana, E. Trx2p-dependent regulation of Saccharomyces cerevisiae oxidative stress response by the $\mathrm{Skn} 7 \mathrm{p}$ transcription factor under respiring conditions. PLoS ONE 2013, 8, e85404. [CrossRef]

67. Lee, J.; Godon, C.; Lagniel, G.; Spector, D.; Garin, J.; Labarre, J.; Toledano, M.B. Yap1 and Skn7 control two specialized oxidative stress response regulons in yeast. J. Biol. Chem. 1999, 274, 16040-16046. [CrossRef]

68. Roetzer, A.; Klopf, E.; Gratz, N.; Marcet-Houben, M.; Hiller, E.; Rupp, S.; Gabaldon, T.; Kovarik, P.; Schuller, C. Regulation of Candida glabrata oxidative stress resistance is adapted to host environment. FEBS Lett. 2011, 585, 319-327. [CrossRef] [PubMed]

69. Kounatidis, I.; Ames, L.; Mistry, R.; Ho, H.L.; Haynes, K.; Ligoxygakis, P. A gost-pathogen interaction screen identifies ada2 as a mediator of Candida glabrata defenses against reactive oxygen species. G3 (Bethesda) 2018, 8, 1637-1647. [CrossRef]

70. Fassler, J.S.; West, A.H. Fungal Skn7 stress responses and their relationship to virulence. Eukaryot. Cell 2011, 10, 156-167. [CrossRef]

(C) 2019 by the authors. Licensee MDPI, Basel, Switzerland. This article is an open access article distributed under the terms and conditions of the Creative Commons Attribution (CC BY) license (http://creativecommons.org/licenses/by/4.0/). 